\title{
Menolak Kekerasan Identitas Tunggal
}

\author{
Oleh Fathurozi \\ Staf Balai Penelitian dan Pengembangan Agama Semarang
}

Indonesia tak bisa terhindar dari namanya konflik suku, ras, agama, dan antargolongan (SARA). Konflik ini hampir setiap tahun terjadi, padahal berbagai cara dilakukan pemerintah dan penggerak kerukunan mulai dari diskusi, seminar dan workshop berbasis kerukunan dalam memutus rantai konflik. Namun konflik tetap terjadi dalam masyarakat yang majemuk.

Rentetan konflik yang menganggu keharmonisan hubungan antar umat beragama di Indonesia yaitu. Pertama, tahun 1998 konflik antar Etnis. Konflik terjadi antara etnis pribumi dan etnis Tionghoa. Kedua, tahun 1999 konflik antar agama di Ambon. Konflik melibatkan umat agama Islam dan Kristen. Ketiga, tahun 2000 konflik antar golongan agama. Kekerasan yang dialami warga Ahmadiyah dan Syiah. Keempat, tahun 2001 konflik antar suku di Sampit, antara warga Dayak dengan Warga Madura. Kelima, tahun 2012 terjadi konflik di Sampang Madura. Konflik ini melibatkan dua aliran agama dalam komunitas muslim Syiah dan Sunni. Keenam, tahun 2015 terjadi konflik agama di Tolikara, Papua. Konflik kaum muslimin dan Kristen.

Konflik yang berbau SARA yang terjadi di Indonesia dan dunia internasional, sebabkan adanya pemaksaan identitas tunggal. Identitas tunggal memandang identitas lainnya penuh kecurigaan, tak ayal kekerasan semakin membara. Padahal identitas bisa dijadikan kekuatan dalam menjalin hubungan antar kelompok keagamaan.

Identitas menjadi penting dalam tataran pemerintahan, orang tanpa identitas tak akan mendapatkan haknya sebagai warga negara. Semisal kasus anak dari aliran kepercayaan tidak naik kelas karena tidak mau mengikuti pelajaran agama yang diakui pemerintah. Kelihatannya identitas takdir yang harus melekat pada tiap manusia.

Dalam buku "Kekerasan dan Identitas" karya Amartya Sen. Sen mengutarakan dalam penggunaan identitas terdapat dua kesalahan yakni. Pertama, memahami bahwa identitas itu secara mutlak bersifat majemuk, dan bahwa taraf kepentingan suatu identitas tidak harus meniadakan kepentingan identitas lainnya. Kedua, seseorang harus mengambil pilihan secara tegas ataupun tidak mengenai kepentingan relatif manakah yang harus diberikan sesuai konteksnya, di antara berbagai kesetiaan dan prioritas yang mungkin saling berebut untuk diutamakan.

Adanya pengotakan identitas seperti agama, etnis, ras akan menimbukan kekerasan karena kecintaanya terhadap kelompoknya melebihi segalanya. Tak heran, jika identitas sering dijadikan alat untuk kepentingan kelompoknya. Sen menceritakan kekerasan komunal di India antara Hindu-Muslim, peristiwa ini terjadi karena adanya pimpinan yang memelintir identitas. Mereka mendoktrin pengikutnya, dengan mengatakan orang Hindu atau orang Islam yang harus balas dendam pada komunitas lain (halaman 221). 
Buku dengan tebal 242 halaman mengunakan analisa kritis. Sen mengkritik Samuel Huntington yakni. Pertama, teori "benturan peradaban" yang mengambarkan "India sebagai peradaban Hindu" merupakan kesalahan besar karena mengabaikan fakta. Menurut Sen, India memiliki penduduk Muslim terbanyak ketiga di dunia. Kurang lebih tercatat 145 juta penduduk muslim di India. Kedua, teori kategorisasi keagamaan seperti peradaban Islam, peradaban Hindu. Sen menjelaskan dengan adanya kategorisasi ini membuat kesalahan karena melihat manusia dari afiliasi tunggal yakni agamanya.

\section{Multikulturalisme}

Islam dewasa ini menjadi agama yang paling banyak diperdebatkan. Sebagian orang berpikir, Islam mencetak fanatisme dan kekerasan. Padahal agama Islam adalah agama damai dan memiliki daya pikat spiritual yang dalam. Namun jika agama dilibatkan dalam poiltik akan menimbulkan perpecahan. Contohnya Spanduk yang bertuliskan "'Masjid Ini Tidak Mensholatkan Jenazah Pendukung dan Pembela Penista Agama" menjelang putaran kedua pilkada DKI. Spanduk ini memunculkan pro kontra di kalangan kaum muslim.

Menurut Sen, menjadi Muslim hampir mustahil menjadi satu-satunya indentitas yang dimiliki seorang Muslim. Contohnya kejadian 11 September pengeboman World Trade Center (WTC) menempatkan kubu umat Muslim saling berseberangan. Hal ini menandakan kaum Muslim tanpa harus meninggal identitas Islamnya dalam menyikapi peristiwa tersebut.

Pasca peristiwa pengeboman WTC sangat penting memahami identitas Muslim yakni. Pertama, memandang kaum Muslim semata-mata atau terutama dalam kerangka kelslaman mereka. Kedua, memahami mereka secara lebih luas dalam kerangka afiliasinya yang beragam (halaman 91 ).

Terkadang dikalangan muslim kurang mampu melihat perbedaan antara menjadi seorang muslim dan memiliki identitas Islam akan terusik dan bertanya 'Manakah pandangan yang benar menurut Islam? Apakah Islam mendukung toleransi, atau tidak? Manakah yang sesungguhnya benar?' Persoalan utama yang kita hadapi di sini bukanlah apa jawaban yang tepat untuk pertanyaan di atas, melainkan apakah pertanyaannya itu sendiri tepat. Menjadi seorang muslim bukanlah suatu identitas mutlak yang menentukan segala keyakinan orang yang bersangkutan" (halaman 84).

Pada tahun 1998 , Amartya Sen menerima penghargaan Nobel bidang ekonomi atas karyanya dalam "Ekonomi Kesejahteraan". Menurut laki-laki kelahiran India, Penganut identitas tunggal kurang memperdulikan sikap toleransi. Padahal tolerasi sangat penting diterapkan dalam masyarakat multikultural.

Sen menunjukan sebagian besar sarjana Muslim menolak mentah-mentah klaim bahwa ajaran Islam mewajibkan atau membolehkan dan bahkan mentolerir terorisme. Buku ini mengajak pembaca merenungi konflik-konflik keagamaan yang terjadi di belahan dunia.

Menurutnya, setidaknya ada dua pendekatan berbeda dalam memandang multikulturalisme. Pertama, memandang bahwa menggencarkan multikulturalisme itu 
sudah dengan sendirinya merupakan nilai yang mesti dibela. Sementara pendekatan yang lain berfokus pada kebebasan dalam menalar dan mengambil keputusan.

Buku ini, menelusuri isu-isu multikulturalisme, pasca-kolonialisme, fundamentalisme, terorisme, dan globali-sasi. Identitas yang kini menjadi pemicu utama pertikaianpertikaian kontemporer. Buku ini layak dibaca untuk menambah wawasan pengetahuan tentang konflik yang terjadi Indonesia dan Dunia internasional.

Dimuat di Jurnal Dialog Vol.40, No.1, Juni 2017

\section{Identitas Buku}

Judul : Kekerasan dan Identitas

Penulis : Amartya Sen

Terjemahan : Arif Susanto

Penerbit : : Marjin Kiri Jakarta

Cetakan : Edisi 2, Februari 2016

Tebal : xxii+242 Halaman

ISBN : : :978-979-1260-54-1 